\title{
11: 101693404-101713675
}

National Cancer Institute

\section{Source}

National Cancer Institute. 11: 101693404-101713675. NCI Thesaurus. Code C41778.

Physical location of BIRC3_Gene 